\title{
Evidence for Identical Dichloromethane Dehalogenases in Different Methylotrophic Bacteria
}

\author{
By DORIS KOHLER-STAUB, ${ }^{1}$ SYBE HARTMANS,${ }^{1} \dagger$ RENE GÄLLI, ${ }^{1}$ \\ FRANZ SUTER ${ }^{2}$ AND THOMAS LEISINGER ${ }^{1 *}$ \\ ${ }^{1}$ Mikrobiologisches Institut and ${ }^{2}$ Institut für Molekularbiologie und Biophysik, Eidgenössische \\ Technische Hochschule, CH-8092 Zürich, Switzerland
}

(Received 3 April 1986; revised 29 May 1986)

\begin{abstract}
The dichloromethane dehalogenases of four facultative methylotrophs that mineralize dichloromethane were compared. Similar levels of specific activity and a similar subunit $M_{\mathrm{r}}$ of the dehalogenases were observed in crude extracts of the four strains. Immunodiffusion analysis and quantitative immunoprecipitation indicated that the dehalogenases closely resemble each other. This was confirmed when the N-terminal amino acid sequences of the four dichloromethane dehalogenases were found to be identical. Some variation was observed with respect to the specificity of the inducers for dichloromethane dehalogenase. In the two Hyphomicrobium strains examined 1,1-dichloroethane and 1,2-dichloroethane were effective gratuitous inducers whereas these compounds exhibited only a marginal inducing effect in the two Pseudomonas strains. The results of this comparative study are compatible with the view that dichloromethane dehalogenase represents a recently evolved enzyme which was horizontally distributed by gene transfer.
\end{abstract}

\section{INTRODUCTION}

Some facultative methylotrophs belonging to the genera Pseudomonas (Brunner et al., 1980; LaPat-Polasko et al., 1984; Gälli \& Leisinger, 1985) or Hyphomicrobium (Stucki et al., 1981) are able to utilize dichloromethane (DCM) as the sole carbon and energy source. The first step in the degradation of this xenobiotic substrate is catalysed by DCM dehalogenase. This enzyme, using reduced glutathione as a cofactor, converts one molecule of dichloromethane into one molecule of formaldehyde and two molecules of hydrochloric acid by nucleophilic substitution of the two halogen atoms with hydroxy-groups. DCM dehalogenase of Hyphomicrobium sp. strain DM2 has recently been purified and characterized (Kohler-Staub \& Leisinger, 1985). It is highly inducible by its substrate and constitutes about $16 \%$ of the total soluble protein in induced cells. Since the enzyme has an unusually low specific activity, such a high intracellular concentration of DCM dehalogenase is needed to permit growth on DCM. The low efficiency of the enzyme is illustrated by its low turnover number of $33 \mathrm{~mol}$ of substrate per mol of enzyme subunit per min. These properties gave rise to the speculation that DCM dehalogenase of Hyphomicrobium represents an enzyme at an early stage in its evolution, whose catalytic activity is still in the process of being improved (Kohler-Staub \& Leisinger, 1985).

Two aspects have led us to characterize and to compare the DCM dehalogenases of additional methylotrophic bacteria that mineralize DCM. Firstly, a microbial process for the degradation of DCM may be of practical interest in the treatment of industrial waste. DCM dehalogenase is the rate-limiting enzyme during growth of Hyphomicrobium DM2 on DCM, and its efficiency is of importance for the maximum degradation rate achieved in a biotechnological process (Gälli

$\dagger$ Present address : Department of Microbiology, Agricultural University, Hesselink van Suchtelenweg 4, 6703 CT Wageningen, The Netherlands.

Abbreviations: DCM, dichloromethane; 1,1-DCE, 1,1-dichloroethane; 1,2-DCE, 1,2-dichloroethane. 
\& Leisinger, 1985). In view of developing an effective degradation process, it was of interest to study the catalytic efficiency of this enzyme in independent isolates. Secondly, it seems possible that the ability to degrade DCM has only recently been acquired in response to the introduction of this xenobiotic substrate into the environment. The evolution process of DCM dehalogenase might thus have proceeded to different stages in different strains. In the study reported here we have examined this possibility by comparing the regulation of DCM dehalogenase formation and the molecular properties of this enzyme from different organisms.

\section{METHODS}

Bacterial strains, media and growth conditions. The bacteria used are listed in Table 1 . They were grown at $30^{\circ} \mathrm{C}$ in batch cultures on a rotary shaker at 120 r.p.m. The minimal medium used contained $\left(\mathrm{g} \mathrm{l}^{-1}\right): \mathrm{KH}_{2} \mathrm{PO}_{4}, 2$; $\mathrm{Na}_{2} \mathrm{HPO}_{4} .2 \mathrm{H}_{2} \mathrm{O}, 4 ;\left(\mathrm{NH}_{4}\right)_{2} \mathrm{SO}_{4}, 1 ; \mathrm{MgSO}_{4} .7 \mathrm{H}_{2} \mathrm{O}, 1 ; \mathrm{pH}$. After sterilization the medium was supplemented with the trace element solution described by Stucki et al. (1981).

When methanol was the carbon and energy source, the substrate concentration was $300 \mathrm{mM}$, and the bacteria were grown in 2-litre Fernbach flasks with 1 litre of medium. Since growth on DCM is inhibited at substrate concentrations above $20 \mathrm{~mm}$, this substrate was added sequentially in two equal portions to 1-litre Erlenmeyer flasks tightly closed with mininert valves (Precision Sampling, Baton Rouge, La., USA) and containing $300 \mathrm{ml}$ medium. Before the addition of the second portion of substrate, the $\mathrm{HCl}$ released into the culture medium as a result of DCM degradation was neutralized with sterile $\mathrm{NaOH}$.

For induction experiments with 1,1-dichloroethane (1,1-DCE) and 1,2-dichloroethane (1,2-DCE) the organisms were grown on minimal medium containing $100 \mathrm{~mm}$-methanol, to which, for the last 24 to $36 \mathrm{~h}$ of cultivation, one of the halogenated ethanes was added at a final concentration of $1 \mathrm{~mm}$. It was verified by $\mathrm{GC}$ analysis that no loss or degradation of 1,1-DCA or 1,2-DCA had occurred during the experiment.

Cells were harvested by centrifugation at the end of the exponential growth phase, washed with $50 \mathrm{~mm}$ Tris $/ \mathrm{HCl}, \mathrm{pH} 7 \cdot 5$, and stored at $-20^{\circ} \mathrm{C}$.

Preparation of cell-free extracts and enzyme assay. Crude extracts were prepared by passing a $20 \%(\mathrm{w} / \mathrm{v})$ cell suspension in $50 \mathrm{~mm}$-Tris/ $\mathrm{HCl}(\mathrm{pH} 7.5), 2.5 \mathrm{mM}-\mathrm{DTT}, 0.1 \mathrm{~mm}$-EDTA, $20 \%$ (v/v) glycerol twice through a French pressure cell at a pressure of $35 \mathrm{MPa}$. Cell debris was removed by centrifugaton at $40000 \mathrm{~g}$ for $30 \mathrm{~min}$. Protein in crude extracts and in purified enzyme preparations was estimated by the method of Bradford (1976) using bovine serum albumin as standard

DCM dehalogenase was assayed by determining the formation of formaldehyde with the 2,4-pentanedione method (Kohler-Staub \& Leisinger, 1985). Enzyme activity is expressed in katals (kat), 1 kat corresponding to the amount of activity catalysing the conversion of $1 \mathrm{~mol}$ substrate $\mathrm{s}^{-1}$

Purification of DCM dehalogenase and SDS-PAGE. DCM dehalogenase of Hyphomicrobium DM2 was purified as described by Kohler-Staub \& Leisinger (1985). The dehalogenases from Pseudomonas DM1, Pseudomonas DM4 and Hyphomicrobium GJ21 were purified by the same method, except that column chromatography on $N$-pentyl Sepharose was omitted

Slab gel electrophoresis. This was done according to the methods of Laemmli (1970) under the conditions described by Kohler-Staub \& Leisinger (1985)

Preparation of antibodies. A $500 \mu \mathrm{g}$ sample of electrophoretically homogeneous DCM dehalogenase from Hyphomicrobium DM2 emulsified in complete Freund's adjuvant was injected intramuscularly and subcutaneously into two rabbits. Three subsequent injections of decreasing amounts of DCM dehalogenase in incomplete Freund's adjuvant were administrated at 2-week intervals. The total amount of DCM dehalogenase used for immunization per rabbit was $1400 \mu \mathrm{g}$. The animals were bled 2 weeks after the final injection. The immunoglobulin $\mathrm{G}$ fraction of the antisera was partially purified by ammonium sulphate precipitation. The two antibody preparations were active with DCM dehalogenase at $10^{4}$-fold and $10^{5}$-fold dilutions, respectively, in an enzyme-linked immunosorbent assay (ELISA) using alkaline phosphatase-labelled anti-rabbit goat immunoglobulin (Sigma) as described by Voller et al. (1976). The activity of the pre-immune sera taken before immunization was 10000 times lower.

Immunodiffusion. Ouchterlony double immunodiffusion analysis was done in $2 \mathrm{~mm}$ gel plates containing $2 \%$ $(\mathrm{w} / \mathrm{v})$ agarose. The central wells were filled with $10 \mu$ undiluted rabbit antibody solution; crude extracts of DCMand methanol-grown cells and purified DCM dehalogenase from Hyphomicrobium DM2 were diluted to a protein concentration of $0.5-2 \mathrm{mg} \mathrm{ml}^{-1}$ and $10 \mu \mathrm{l}$ of each was placed in the outer wells. After $18 \mathrm{~h}$ at $4{ }^{\circ} \mathrm{C}$ diffusion was stopped by washing the gels extensively with $\mathrm{PBS}\left(8 \cdot 0 \mathrm{~g} \mathrm{NaCl}, 0 \cdot 2 \mathrm{~g} \mathrm{KCl}, 1.44 \mathrm{~g} \mathrm{Na}_{2} \mathrm{HPO}_{4} \cdot 2 \mathrm{H}_{2} \mathrm{O}, 0 \cdot 2 \mathrm{~g} \mathrm{KH}_{2} \mathrm{PO}_{4}\right.$ in $1000 \mathrm{ml}$ distilled $\mathrm{H}_{2} \mathrm{O}$ ). After drying the gels, the precipitin lines were stained with Serva Blue $\mathrm{G}$.

Quantitative immunoprecipitation. Antigen solutions were crude extracts except in the case of Pseudomonas DMI, where an enzyme preparation purified by DEAE-cellulose chromatography was used. They were diluted with PBS to give $3.3 \mathrm{nkat} \mathrm{DCM}$ dehalogenase $\mathrm{ml}^{-1}$. Antigen solution $(100 \mu \mathrm{l})$ was mixed with $50 \mu \mathrm{l}$ of appropriately diluted (0.05-0.5 mg protein per $\mathrm{ml}$ PBS) antibody solution and incubated for $1 \mathrm{~h}$ at $30^{\circ} \mathrm{C}$. A $50 \mu \mathrm{l}$ volume of a $10 \%(\mathrm{w} / \mathrm{v})$ 
Table 1. Induction of DCM dehalogenase

Specific enzyme activities were determined in crude extracts from cells grown on DCM, on methanol or on methanol plus one of the non-degradable compounds 1,1-DCE or 1,2-DCE.

\begin{tabular}{|c|c|c|c|c|}
\hline & \multicolumn{4}{|c|}{$\begin{array}{c}\text { DCM dehalogenase specific activity } \\
\left.[\text { mkat (kg protein })^{-1}\right]\end{array}$} \\
\hline & \multicolumn{4}{|c|}{ Growth on medium containing: } \\
\hline Strain* & DCM & Methanol & $\begin{array}{c}\text { Methanol } \\
+ \\
1,1-\mathrm{DCE}\end{array}$ & $\begin{array}{c}\text { Methanol } \\
+ \\
1,2-\mathrm{DCE}\end{array}$ \\
\hline Pseudomonas sp. DMI (DSM 1565) & $4 \cdot 50$ & $<0.02$ & $0 \cdot 33$ & $0 \cdot 27$ \\
\hline Hyphomicrobium sp. DM2 (ATCC 43129) & $3 \cdot 83$ & $<0.02$ & $4 \cdot 17$ & $2 \cdot 12$ \\
\hline Pseudomonas sp. DM4 & $4 \cdot 32$ & $0 \cdot 08$ & $0 \cdot 27$ & 0.45 \\
\hline Hyphomicrobium sp. GJ21 & 4.83 & $0 \cdot 12$ & 3.50 & $2 \cdot 67$ \\
\hline
\end{tabular}

* Strain DMI was isolated by enrichment culture from air in Switzerland (Brunner et al., 1980), strain DM2 from soil in Switzerland (Stucki et al., 1981), strain DM4 from soil in Germany (Gälli \& Leisinger, 1985), and strain GJ21 from soil in the Netherlands (obtained from D. Janssen, University of Groningen, the Netherlands).

suspension of Staphylococcus aureus cells (Pansorbin, Calbiochem-Behring) in PBS was added and incubation at $30^{\circ} \mathrm{C}$ was continued for $60 \mathrm{~min}$. Immunocomplexes were sedimented by 2 min centrifugation in an Eppendorf microfuge and the supernatant was removed for assaying DCM dehalogenase activity. The titre was defined as the amount of antibody that precipitated $50 \%$ of the antigen activity. The index of dissimilarity indicates the weight ratio of antibodies needed to precipitate $50 \%$ of the heterologous and the homologous antigen.

Immunoblotting (Western blotting). After separation by SDS-PAGE the proteins were electrophoretically transferred at a constant voltage of $70 \mathrm{~V}$ for $90 \mathrm{~min}$ from the polyacrylamide gel onto a nitrocellulose sheet in a BioRad Trans Blot electrophoretic transfer cell according to Towbin et al. (1979). Blotting buffer was composed of $25 \mathrm{~mm}$-Tris, $192 \mathrm{~mm}$-glycine, $10 \%$ (v/v) methanol, 0.02\% (w/v) SDS, pH $8 \cdot 3$.

Rabbit antibodies against purified DCM dehalogenase were used for antigen detection. After incubation overnight at $4{ }^{\circ} \mathrm{C}$ in PBS containing $10 \%$ (v/v) new-born calf serum (Gibco) (PBS/NBCS) the nitrocellulose sheet was placed into a rabbit antibody solution diluted $10^{5}$-fold with PBS/NBCS. After $4 \mathrm{~h}$ incubation at room temperature the nitrocellulose sheet was washed in PBS, then incubated for $2 \mathrm{~h}$ at room temperature with goat anti-rabbit IgG conjugated to horseradish peroxidase (Calbiochem), diluted $10^{3}$-fold in PBS/NBCS. After repeated washes in PBS the nitrocellulose sheet was developed with $0.02 \%(w / v)$ chloronaphthol dissolved in $20 \mathrm{~mm}$-Tris/ $\mathrm{HCl}$ buffer, pH 7.5, containing $150 \mathrm{~mm}-\mathrm{NaCl}, 0 \cdot 5 \mathrm{mM}-\mathrm{MgCl}_{2}, 0 \cdot 15 \mathrm{~mm}-\mathrm{CaCl}_{2}$ and $0 \cdot 2 \mu \mathrm{l} \mathrm{H}_{2} \mathrm{O}_{2}(30 \%)$ $\mathrm{ml}^{-1}$. The reaction was stopped by washing with distilled water.

$N$-terminal amino acid sequence analysis. This was done on a Beckman $890 \mathrm{C}$ sequencer; 30 nmol enzyme subunits were used per run. Polybrene served as a carrier. The degradation of the peptides was performed using a Quadrol programme supplied by Beckman Instruments. The anilinothiazolinones were converted and identified as phenylthiohydantoin derivatives of amino acids by high-performance liquid chromatography as described by Frank \& Zuber (1976). Arginine and histidine were identified directly by reversed-phase high-performance liquid chromatography.

\section{RESULTS AND DISCUSSION}

\section{DCM dehalogenase activities in crude extracts}

The bacteria whose DCM dehalogenases were examined are listed in Table 1. They were isolated from enrichment cultures in DCM-minimal medium which had been inoculated with samples from different environments. Non-identity of the strains was indicated by the fact that the two pseudomonads and the two hyphomicrobia differed from each other with respect to substrate profiles and antibiotic sensitivities. Furthermore, Pseudomonas sp. strain DM4 produced a red pigment while strain DMI was colourless.

All four isolates exhibited comparable growth rates of $0.07-0.09 \mathrm{~h}^{-1}$ on DCM, and crude extracts of the organisms showed similar DCM dehalogenase specific activities that ranged between 3.8 and $4.8 \mathrm{mkat}(\mathrm{kg} \text { protein })^{-1}$ (Table 1 ). Since in all strains this activity was strictly dependent on reduced glutathione, the enzymic dehalogenation of DCM seems to be based on 

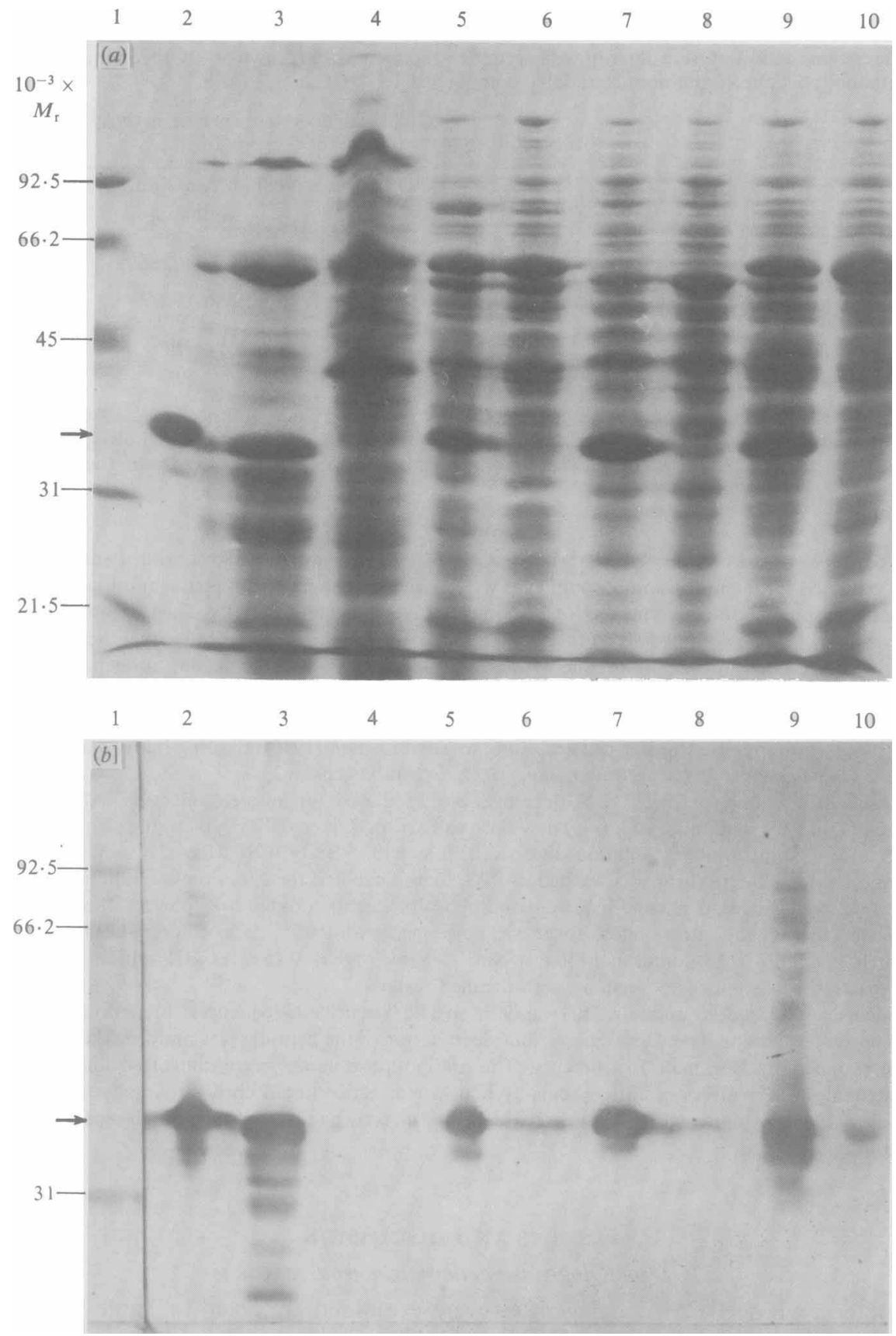

Fig. 1 (a) SDS-PAGE of extracts of DCM-grown cells (lanes 3, 5, 7, 9; $70 \mu \mathrm{g}$ protein per lane) and of extracts of methanol-grown cells (lanes $4,6,8,10 ; 60 \mu \mathrm{g}$ protein per lane). Lanes: (1) standard proteins, $5 \mu \mathrm{g}$ each; (2) pure DCM dehalogenase of strain DM2, $20 \mu \mathrm{g}$ protein; (3) and (4) strain DM1 : (5) and (6) strain DM2; (7) and (8) strain DM4; (9) and (10) strain GJ21. (b) Immunoblot analysis showing rabbit antibodies against purified DCM dehalogenase from strain DM2 reacting with DCM dehalogenase in extracts of DCM-grown cells (lanes 3, 5, 7, 9;10 $\mu \mathrm{g}$ protein per lane) and in extracts of methanol-grown cells (lanes $4,6,8,10 ; 10 \mu \mathrm{g}$ protein per lane). The contents of the lanes are as for $(a)$. Standard proteins were stained with amido black after blotting onto the nitrocellulose sheet. The arrow indicates the position of a $33 \mathrm{kDa}$ antigen recognized by the antibodies in all samples examined except the extract of strain DM1 grown on methanol. 

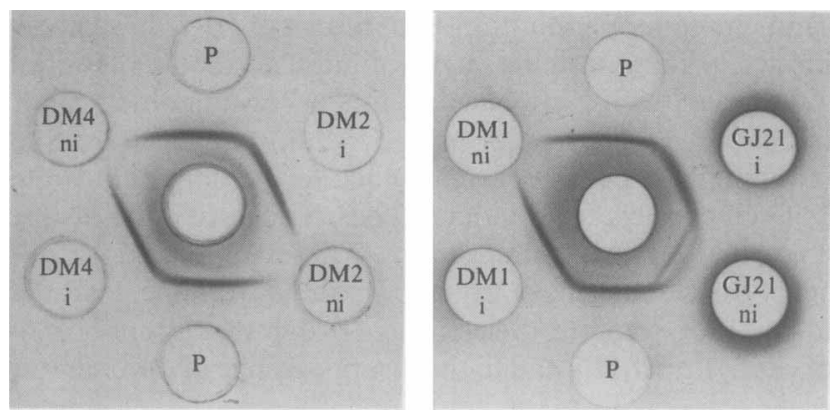

Fig. 2. Double immunodiffusion analysis. The central wells contained $10 \mu 1$ undiluted antibody solution. The outer wells were filled with $10 \mu \mathrm{l}$ cell extract $(20 \mu \mathrm{g}$ protein) or with $10 \mu \mathrm{l}$ of purified DCM dehalogenase from Hyphomicrobium DM2 $(5 \mu \mathrm{g}$ protein; P). ' $i$ ' denotes that the cell extract was obtained from DCM-grown cells that were induced for DCM dehalogenase; 'ni' indicates cell extract from noninduced, methanol-grown cells.

the same mechanism. The analysis of crude extracts by SDS-PAGE indicated that the subunit $M_{\mathrm{r}}$ of the dehalogenase was closely similar in the four organisms. A prominent protein band corresponding to an $M_{\mathrm{r}}$ of approx. 33000 was detected in all extracts of DCM-grown cells (Fig. $1 a)$. It exhibited the same electrophoretic mobility as the purified DCM dehalogenase from Hyphomicrobium DM2. The intensity of the $33 \mathrm{kDa}$ band relative to the other bands shows that DCM dehalogenase represents a significant portion of the total protein in crude extracts of induced cells. The four organisms thus do not differ significantly with respect to the catalytic efficiency of their DCM-dehalogenases.

There were differences between the organisms in the induction of DCM dehalogenase activity. In all strains the enzyme was highly inducible by DCM (Table 1, Fig. 1a). However, strong gratuitous induction by 1,1-DCE or 1,2-DCE, which do not serve as enzyme or growth substrates, was only observed in the two Hyphomicrobium strains (Table 1). It is possible that the DCM utilization systems of the two hyphomicrobia are at a more advanced stage in their evolution than those of the Pseudomonas strains. In the Hyphomicrobium strains mutations in a gene governing dehalogenase synthesis may have led to a situation in which the dehalogenase is formed when the potential substrates 1,1-DCE or 1,2-DCE are present in the environment. Thus, possibly the two organisms could acquire the ability to degrade these substrates by further mutation(s) in the dehalogenase structural gene. This sequence of events, regulatory gene mutations preceding subsequent structural gene mutations leading to altered substrate specificity of an enzyme, has been documented in several cases of enzyme evolution (Clarke, 1980).

\section{Immunological comparison of DCM dehalogenases}

Immunodiffusion on Ouchterlony plates was used to examine the cross-reactivity of antibodies against purified DCM dehalogenase from the reference strain Hyphomicrobium DM2 with crude extracts from the other DCM-degrading strains. Strong precipitin bands were formed with cell extracts of all four strains grown on DCM (Fig. 2). All bands fused with the precipitin band of pure DCM dehalogenase, and spurs were not formed. The organisms examined thus appear to form immunologically similar DCM dehalogenases.

The immunological relationships between the DCM dehalogenases of Pseudomonas DM1 and the dehalogenases of the other strains were also explored by quantitative immunoprecipitation. As compared to a dissimilarity index of 1.0 for the homologous antigen from Hyphomicrobium DM2, the indices of dissimilarity of the three heterologous antigens from Pseudomonas DM1, Pseudomonas DM4 and Hyphomicrobium GJ21 were 0.6. These strong cross-reactions indicate that the four DCM dehalogenases closely resemble each other. Immunoblotting analysis (Fig. 1 b) confirmed the high degree of relatedness between the dehalogenases suggested by the double 
immunodiffusion and immunoprecipitation experiments. To reduce non-specific binding of antibodies to the blotted cellular proteins, highly diluted antibody solutions were used. All four samples from DCM-grown cells produced a major immunoblot band whose $R_{F}$ value corresponded to that of pure DCM dehalogenase. With respect to electrophoretic mobility, size and intensity these immunoblot bands corresponded to the dominant protein bands observed upon SDS-PAGE of cell extracts from induced cells. The antibodies also reacted with blotted proteins of lower $M_{\mathrm{r}}$ than DCM dehalogenase. These immunoblot bands are assumed to represent fragments of the dehalogenase which originated from the degradation of the enzyme. In extracts of strain DM1 for example, the enzyme was digested by endogenous proteases, which led to a rapid loss of catalytic activity and to the disappearance of the characteristic protein band on SDS gels.

In control experiments crude extracts of five facultative methylotrophs that were unable to degrade DCM but had been grown on $150 \mathrm{~mm}$-methanol plus $5 \mathrm{mM}$-DCM were subjected to electrophoresis and subsequent immunoblot analysis. No bands reacting with the antibody against DCM dehalogenase were observed.

\section{$N$-terminal amino acid sequence}

The structural relatedness of the DCM dehalogenases was further explored by a comparison of their $\mathrm{N}$-terminal amino acid sequences. Partially purified enzyme preparations of about $90 \%$ purity as judged by SDS-PAGE were sequenced up to residue 15. The sequences obtained were completely homologous:

\section{(Met)-Ser-Pro-Asn-Pro-Thr-Asn-Ile-His-Thr-Gly-Lys-Thr-Leu-Arg-}

All the enzymes had a heterogeneous $\mathrm{N}$-terminus, which consisted partially of methionine and partially of serine, in a ratio which varied between $1: 1$ and $1: 2$. This indicates that in the cell the post-translational removal of the $\mathrm{N}$-terminal methionine residue is not carried out to completion. In general the $\mathrm{NH}_{2}$ - or $\mathrm{COOH}$-terminal tails are of minor importance for the structural conformation and for the catalytic activities of proteins. These regions of protein molecules are therefore particularly susceptible to mutational changes leading to sequence variation (Hartley, 1984). The fact that the $\mathrm{N}$-terminal amino acid sequence of the DCM dehalogenases from four different organisms were identical thus provides a strong argument for a very recent common origin of these enzymes. At this point it cannot be decided whether the dehalogenase structural gene was horizontally distributed among the four isolates studied or whether it recently evolved in different organisms and at different locations from a common ancestor gene.

The uniform enzyme pattern encountered in DCM-degrading soil bacteria is in contrast to the variety of haloalkanoic acid dehalogenases found in bacteria growing on halogenated alkanoic acids as their carbon and energy sources (Hardman \& Slater, 1981). Two, three or four separate dehalogenases with overlapping substrate and inducer specificities have been observed. The physiological significance of possessing more than one dehalogenase is not clear. On the basis of the reaction mechanisms operated by these enzymes it appears that two mechanistically unrelated types of dehalogenases have evolved in parallel (Weightman et al., 1982). Although there are a number of theoretically possible enzyme mechanisms for the dehalogenation of DCM, we have observed only one type of enzyme performing this reaction. This may be related to the fact that DCM is a xenobiotic compound which has been present in the environment in significant concentrations only for about forty years. Consequently, selective pressure for the evolution of DCM-dehalogenating enzymes has existed only for a comparatively short time.

We thank Dr Christian Heusser, Ciba-Geigy AG, for the preparation of anti-serum. This work was supported by a grant from the Swiss Federal Institute of Technology, Zürich, Switzerland, and by Ciba-Geigy AG, Basel, Switzerland. 


\section{REFERENCES}

BRADFord, M. (1976). A rapid and sensitive method for the quantitation of microgram quantities of protein utilizing the principle of protein-dye binding. Analytical Biochemistry 72, 248-254.

Brunner, W., Staub, D. \& Leisinger, T. (1980). Bacterial degradation of dichloromethane. Applied and Environmental Microbiology 40, 950-958.

Clarke, P. H. (1980). Experiments in microbial evolution: new enzymes, new metabolic activities. Proceedings of the Royal Society B207, 385-404.

FranK, G. \& ZUBER, H. (1976). The complete amino acid sequences of both subunits of the sweet protein monellin. Hoppe-Seyler's Zeitschrift für physiologische Chemie 357, 585-592.

GÄLLI, R. \& LeISINGER, T. (1985). Specialized bacterial strains for the removal of dichloromethane from industrial waste. Conservation and Recycling 8, 91100.

Hardman, D. J. \& Slater, J. H. (1981). Dehalogenases in soil bacteria. Journal of General Microbiology $123,117-128$

HARTLEY, B. S. (1984). Experimental evolution of ribitol dehydrogenase. In Microorganisms as Model Systems for Studying Evolution, pp. 23-54. Edited by R. P. Mortlock. New York: Plenum Press.

Kohler-Staub, D. \& Leisinger. T. (1985). Dichloromethane dehalogenase of Hyphomicrobium sp. strain DM2. Journal of Bacteriology 162, 676-681.

LAEMmLI, U. (1970). Cleavage of structural proteins during the assembly of the head of bacteriophage T4. Nature, London 227, 680-685.

LaPat-Polasko, L. T., McCarty, P. L. \& Zehnder, A. J. B. (1984). Secondary substrate utilization of methylene chloride by an isolated strain of Pseudomonas sp. Applied and Environmental Microbiology 47, 825-830.

StUCKI, G., Gälli, R., Ebersold, H.-R. \& Leisinger, T. (1981). Dehalogenation of dichloromethane by cell extracts of Hyphomicrobium DM2. Archives of Microbiology 130, 366-371.

Towbin, H., Staehelin, T. \& Gordon, J. (1979). Electrophoretic transfer of proteins from polyacrylamide gels to nitrocellulose sheets: procedure and applications. Proceedings of the National Academy of Sciences of the United States of America 76, 43504354.

Voller, A., Bidwell, D. \& Bartlett, A. (1976). Microplate enzyme immunoassays for the immunodiagnosis of virus infections. In Manual of Clinical Immunology, pp. 506-512. Edited by N. Rose \& H. Friedman. Washington, DC: American Society for Microbiology.

Weightman, A. J., Weightman, A. L. \& Slater, H. J. (1982). Stereospecificity of 2-monochloropropionate dehalogenation by the two dehalogenases of Pseudomonas putida PP3: evidence for two different dehalogenation mechanisms. Journal of General Microbiology 128, 1755-1762. 